\title{
СТРУКТУРА ШТУЧНИХ БУДІВЕЛЬНИХ МАТЕРІАЛІВ І ЇЇ ОСОБЛИВОСТІ
}

\section{STRUCTURE OF ARTIFICIAL BUILDING MATERIALSAND ITS FEATURES}

\section{Коверніченко Л.М., к.т.н, доцент (ДВНЗ КНУ, м.Кривий Ріг)}

Kovernichenko L.M., Ph.D. in Engineering, Associate Professor (State Higher Educational Institution Kryvyi Rih National University, Kryvyi Rih)

У статті описано різновиди в'яжучої речовини, які зумовлюють утворення особливої мікроструктури, пов'язані 3 переважанням певних кристалічних форм новоутворень.

Introduction. Structure consists of a binder, filler material and capillary-porous parts. These features are the kind of astringent that is used for the material, as well as in specific quantitative ratios of the binding and filler parts; in the nature of contacting these parts with each other on the surfaces of their section. The features, in addition, include a number of physical characteristics, the materials differ from each other texture, color, weight, the ability of the structure to withstand the influence of thermal and mechanical factors, such as erasure, shock and static loads, high and low temperatures.

Goal. The aim is to study the types of astringent substances that determine the features of microstructure associated with the predominance of certain crystalline forms of tumors. For example, in the interaction of semi-aquatic gypsum with water, needle crystals of dihydrogen gypsum are formed, are closely interwoven with each other, and with age, solidification of gypsum stone increases in their sizes.

Methods of research. When hardening of Portland cement dough, tumors arise in various crystalline forms, which largely depends on the temperature of the medium and the concentration of calcium oxide hydrate in the liquid phase. The most characteristic is the formation of supersaturated solutions and geloid masses. They have crystallization centers that cause the formation of submicrocrystalline particles of 
calcium hydrosilicates, relatively large crystals of calcium oxide hydrate, hexagonal plates of calcium hydroaluminates, usually crystallize around $\mathrm{C}_{3} \mathrm{~A}$ grains, other forms of tumors are isolated. When hardening of caustic magnesite, crystals of magnesium oxychloride grow in amorphous mass of magnesium oxide hydrate. The results of research. When hardening of the ceramic solution, crystalline mullite cemented with a glass of fusible eutectics is isolated. Similarly, microstructures of other hardened astringent substances are studied, which are studied by means of microscopic studies in reflected light, a set of optical characteristics, indicators of light refraction, the shape of crystalline grains, coloring, cleavage cracks, and others. The kind of filler material is rather vivid and directly characterizes the macrostructure of products, especially when studying the sills, it determines its physical characteristics. On the basis of the same binder, for example, Portland cement, products can be made with different fillers - dense crushed stone and sand in heavy cement concrete, porous gravel and sand in light cement concrete, asbestos in asbestos cement products, crushed wood and arbolit, wood wool in fibrolite, granular polystyrene in porous concrete, quartz sand in building solutions, etc.

Conclusions Thus, in addition to the aforementioned pores, the astringent parts may have relatively large spherical pores of the size from $50-100 \mu \mathrm{m}$ to $2-5 \mathrm{~mm}$, which are formed in different quantities depending on whether they are involuntarily or arbitrarily formed. If they arise due to spontaneous air involvement in the manufacture of a mixture of components, then their number is usually small (2-5\%), but if they arise under the influence of special airborne or pore forming, burnt out during incineration, and other additives, then cropped in ' The tangent substance can concentrate up to $50 \%$ or more spherical pores, most often closed.

Ключові слова: будівельні матеріали, структура, пори, пустоти. Key words: building materials, structure, pores, voids.

Вступ. Структура складається 3 в'яжучої речовини, заповнюючого матеріалу i капілярно-порової частини. Ці особливості полягають у різновиду в'яжучої речовини яка використовується для матеріалу, а також в конкретних кількісних співвідношеннях в'яжучої i заповнюючої частин; в характері контактування цих частин між собою по поверхнях їх розділу. До особливостей, крім того, відноситься ряд фізичних ознак, матеріали 
розрізняються між собою, - текстурою, кольором, вагою, здатністью структури протистояти впливу теплових і механічних факторів, наприклад стирання, ударним і статичних навантажень, високих і низьких температур.[1]

Аналіз останніх досліджень. У в'яжучої частині і контактній зоні переважають пори порівняно малих розмірів, тоді як в заповнюючій частині зосереджуються макропори i iнші нещільності. Всі види пір і нещільності в кінцевому рахунку впливають на інтегральну величину пористості і відображаються на величині об'ємної маси, а також на всіх основних характеристиках міцності, морозостійкості, водопоглинанні і т.п.Пори в'яжучої частини мають різне походження, що залежить від виду застосовуваного цементуючого матеріалу.[2]

Постановка мети і задач досліджень. Метою являється дослідження різновидів в'яжучої речовини які зумовлюють особливості мікроструктури, що пов'язані 3 переважанням певних кристалічних форм новоутворень. Так, наприклад, при взаємодії напівводного гіпсу 3 водою утворюються голчасті кристали двуводного гіпсу, тісно переплітаються між собою i 3 віком твердіння гіпсового каменю збільшуються в своїх розмірах.

Методика досліджень. При затвердінні портландцементного тіста виникають новоутворення в різних кристалічних формах, що в значній мірі залежить від температури середовища і концентрації гідрату окису кальцію в рідкій фазі. Найбільш характерним $\epsilon$ утворення пересичених розчинів i гельовидних мас. У них виникають центри кристалізації, які обумовлюють формування субмікрокристалічних частинок гідросилікатів кальцію, утворюються відносно великі кристали гідрату окису кальцію, гексагональних пластинок гідроалюмінатов кальцію,кристалізуються зазвичай навколо зерен $\mathrm{C}_{3} \mathrm{~A}$, виділяються інші форми новоутворень. При твердінні каустичного магнезиту виростають кристали оксихлорида магнію в аморфній масі гідрату окису магнію.[3]

Результати досліджень. При затвердінні керамічного розчину виділяються кристали муллита, зцементованого склом легкоплавких евтектик. Аналогічним чином виникають мікроструктури інших затверділих в'яжучих речовин, що вивчаються за допомогою мікроскопічних досліджень у відбитому світлі, комплексу оптичних характеристик-показників світлопереломлювання, форми 
кристалічних зерен, забарвлення, тріщин спайності і ін.

Різновид заповнюючого матеріалу досить яскраво i безпосередньо характеризує макроструктуру виробів, особливо при вивченні шліфів, зумовлює його фізичні характеристики. На основі одного і того ж в'яжучого, наприклад портландцементу, вироби можуть виготовлятися 3 різними наповнювачами - щільним щебенем і піском в важких цементних бетонах, пористим щебенем $\mathrm{i}$ піском в легких цементних бетонах, азбестом в азбестоцементних виробах, дробленки деревини i арболіта, деревної шерсті в фіброліті, гранульованим полістиролом в поризованих бетонах, кварцовим піском в будівельних розчинах i т.п. По виду цих заповнюючих матеріалів складається перше враження про характер виробів, очікувані показників його фізичних, механічних i технологічних властивостей, експлуатаційних якостях i довговічності. (Рис1,2).

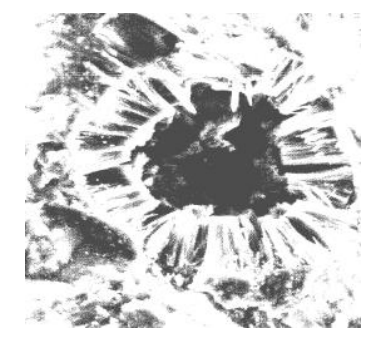

Рис.1. Кальцит і арагоніт

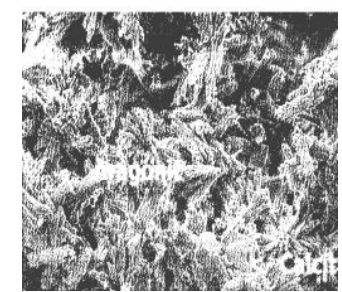

Рис.2. Кальцит і ватеріт

Характер пористості $\epsilon$ найважливішою специфічною особливістю. Виключити 3 обсягу пори і капіляри практично не представляється можливим. Пористість будівельних матеріалів коливається в дуже широких межах: від 0 (скло) до 95\% і вище 
(плити з мінеральної вати тощо). У виробах пори, а також інші види нещільності (мікро-імакротрещіни, раковини і каверни, порожнини і порожнечі) зосереджені в в'яжучої частині, що заповнює частини i в контактній зоні, тобто по поверхнях розділу цих двох структурних компонентів. У в'яжучої частині і контактній зоні переважають пори порівняно малих розмірів, тоді як в заповнюйочий частині зосереджуються макропори i інші нещільності. Всі види пір i нещільності в кінцевому рахунку впливають на інтегральну величину пористості і відображаються на величині об'ємної маси, а також на всіх основних характеристиках - міцності, морозостійкості, водопоглинанні i т.П. Пори в'яжучої частини мають різне походження, що залежить від виду застосовуваного цементуючого матеріалу.

При використанні неорганічних в'яжучих речовин, що заповнені водою або водними розчинами деяких солей, мікро i макропор в'яжучої частини пов'язані 3 процесами на стадіях твердіння і зміцнення. В цей досить невизначений за часом період з'являються, по-перше, пори гелю, що виникли як проміжки між його частинками за рахунок синерезиса і випаровування води, яка адсорбционно звязана з його мицеллами, розмір яких, як вважають, дорівнює в межах від $2 \times 10^{-7}$ до $4 \times 10^{-7} \mathrm{~cm}$, а за характером вони в основному замкнуті. По-друге, утворюються пори за рахунок усадочних явищ при хімічній взаємодії реагуючих інгредієнтів, які зазвичай називають контракціоними і які за своїм розміром перевищують гелеві пори, складаючи приблизно $5 \times 10^{-7}$ до $20 \times 10^{-7}$ см. При випаровуванні капілярної вологи, розташованої між агрегатами гелю (роями мицелл), утворюються- потретє, капілярні пори, розмір яких в поперечнику становить від $1000 \times 10^{-7}$ до $50000 \times 10^{-7} \mathrm{~cm}$, тобто за своїм характером в тисячі разів більше, ніж пори гелю. Капілярні пори в основному відкриті і сполучаються між собою [4].

Кількісний вміст різних пір можна 3 відомим наближенням визначити розрахунковим шляхом або добре розробленими експериментальними методами порометрії. Різноманіття розміру пір дозволяє відзначити, що затверділий камінь неорганічного в'яжучї речовини, наприклад цементний камінь, характеризується неоднорідною пористістю структури. У порах може утримуватися значна кількість води, по різному пов'язаної з твердою фазою а, отже, має 3 нею диференційний характер характер зв'язку і по 
міцності, і по товщині плівок (вода гідратних і високогідратних з'єднань, сорбирована, гігроскопічна в мікропорах, вільна в мікропорах, вільна в великих порах).Кількість всих видів води в порах і капілярах є змінним і змінюється в міру протікання процесів твердіння тіста і випаровування з нього вільної води.

Застосування полімерних матеріалів як сполучний компонент в суміші 3 мікронаповнювачами також призводить до деякої пористості в'яжучої частини. Пори виникають в результаті випаровування продуктів поліконденсації, якщо використовуються термоактивні олігомери і полімери в ході контракції. За розміром вони відносяться до мікропор і так само, як і при інших в'яжучих, кількість їх і розмір змінюються в наступний період формування структури.У випалювальних в'яжуча частина має пори капілярні і замкнуті за рахунок часткового виходу газоподібних продуктів розкладання і термальних реакцій.

Висновки. Таким чином, крім зазначених вище пор у в'яжучих частинах можуть знаходиться порівняно великі сферичної форми пори розміром від 50-100 мкм до 2-5 мм, які утворюються в різних кількостях залежно від того, мимоволі або довільно вони утворені. Якщо вони виникають внаслідок мимовільного залучення повітря при виготовленні суміші компонентів, то їх кількість зазвичай невелика (2-5\%), але якщо вони виникають під впливом спеціальних повітряно залучающих або пороутворюючих, що вигоряють при випалюванні, і інших добавок, то в поризованій в'яжучий речовині може зосереджуватися до $50 \%$ i більше сферичних пор, найчастіше замкнутих.

1.Коверніченко Л.М. Заповнювачі для бетону і взаємодія їх з водою/ Коверніченко Л.М. Збірник наукових праць.Сучасні технології та методи розрахунків у будівництві. Луцьк ЛНТУ, 2017,№8.- С.103-110.

2.Шишкін О.О. Спеціальні бетони для підсилення будівельних конструкцій, що експлуатуються в умовах дії агресивних середовищ/ Шишкін О.О. Навчальний посібник для студентів ВНЗ - Кривий Ріг: Мінерал, 2001. - 113 с.

3.Штарк Иохен, Вихт Бернд. Долговечность бетона / Пер. с нем. - А. Тулаганова. Под ред. П. Кривенко, Техн. ред. Е. Кавалеровой. Киев: Оранта, 2004. - 301 с.

4.Пунагин В.Н.Долговечность бетонных и железобетонных изделий и конструкций / Пунагин В.Н., Приходько А.П., Савицкий Н.В. Учебное пособие для студентов ВУЗов. - Киев: УМК ВО, 1988. - 112 с. 